\title{
Forum
}

\section{Disenfranchisement of Countries and Civil Society at COP-15 in Copenhagen}

Ian M. McGregor*

Civil society participation in global environmental and other arenas of transnational politics, particularly in open international institutions such as the UNFCCC at COP-15, involves both insider and outsider coalitions and strategies. ${ }^{1}$ Insider strategies seek to influence government officials directly through lobbying. Outsider strategies use demonstrations, media and other activism to put public pressure on government officials. ${ }^{2}$ As a civil society representative at Copenhagen COP-15, I offer an alternative interpretation of the major causes of disenfranchisement to Fisher's. ${ }^{3}$ According to Fisher, "the addition of the climate justice movement to the repertoire of action at this round of negotiations ended up leaving civil society out in the cold."

Fisher claims that three forces led to the disenfranchisement of civil society at COP-15: increased registration, poor planning and "the merging of movements. ${ }^{5}$ While poor planning was clearly an issue, this paper demonstrates that the other forces of increased registration and what Fisher calls the "merging of movements" contributed to more effective participation and influence by civil society, particularly environmental and climate justice groups. Civil society groups did not contribute to the development of the Copenhagen Accord; many supported the disenfranchised countries that rejected the Accord as inadequate and undemocratic.

* Please direct all correspondence to: Ian M McGregor, Lecturer, School of Management, University of Technology Sydney (UTS), PO Box 123, Broadway, NSW 2007, Australia. Email: ian.m .mcgregor@uts.edu.au. The author would like to thank both the editors of the journal and the anonymous reviewers for their comments on earlier versions of this article.

1. Sikkink 2005.

2. See Tarrow 2005; and della Porta and Tarrow 2005.

3. Fisher 2010.

4. Fisher 2010, 16.

5. Fisher 2010, 11.

Global Environmental Politics 11:1, February 2011

๑ 2011 by the Massachusetts Institute of Technology 


\section{Civil Society and COP-15}

At COP-15, there were strong and coordinated outsider and insider strategies used particularly by three environmental and climate justice groupings: Climate Action Network (CAN), Global Climate Change Alliance (GCCA) and 350.org. Efforts by these groups to influence agenda-setting for COP-15 in 2009 have continued since COP-13 in Bali in 2007. One of the most effective efforts to influence the agenda was undertaken by 350. org and its GCCA and CAN allies. By the end of COP-15, "the 350 ppm [parts per million] target, which once seemed so obscure, had become an object of plain speech, had been endorsed by 112 countries, and had in many ways supplanted the $2{ }^{\circ} \mathrm{C}$ temperature target as the mark and measure of true climate stabilization." 6 Thousands of civil society groups campaigned extensively to achieve this in the lead-up to COP-15, including over 5,000 350.org events in 181 countries on October 24, 2009. CNN called this "the most widespread day of political action in the planet's history." 7 Gaining the support of 112 countries for the 350ppm target was also a major achievement. ${ }^{8}$ As Bill McKibben, a founder of 350.org, commented, however, it was not the right 112 countries that endorsed the 350ppm target. ${ }^{9}$ The EU, US, China and India have not endorsed it.

CAN and GCCA brought together a global network of over 450 environmental and climate justice NGOs from almost all nations. Before COP-15, they had agreed through CAN a 10-page document outlining the essential elements for a successful, "fair, ambitious and binding" climate deal. ${ }^{10}$ This formed the focus for CAN and its allies' strategy and communications throughout COP-15. In terms of agenda-setting, the terminology of a "fair, ambitious and binding" outcome became widely used by the environmental and climate justice groups and by many vulnerable countries pushing for a strong agreement at COP- 15 .

\section{Insider and Outsider Coalitions and Strategies at COP-15}

During the first week of negotiations, there were no restrictions on registered NGO delegates' access to the Bella Center in Copenhagen where COP-15 was held. At the Bella Center Metro station, civil society groups were protesting and distributing information to the large number of government and other delegates arriving at and leaving the negotiations. Although, as is usual in the UNFCCC negotiations, NGO delegates are not normally allowed access to the formal negotiations on the proposed text, a number of NGO delegates who were members of official national delegations and other friendly members of national delegations kept interested civil society delegates well informed of the

\footnotetext{
6. Athanasiou 2010.

7. 350.org 2009a.

8. 350.org 2009b.

9. Presentation by Bill McKibben to 350.org Australia, 20 May 2010.

10. CAN 2009, 2.
} 
negotiations' progress or lack thereof. The NGO delegates were also lobbying government officials.

On the afternoon of the first Wednesday of COP-15, there was a hastily organized noisy demonstration inside the COP. Videos of this were posted on YouTube. ${ }^{11}$ This demonstration was in support of Tuvalu and its powerful, widely applauded, speech supporting its proposed Protocol that morning in the COP Plenary. Later that day, "NGOs from around the world united in voting Tuvalu the first ever winner of Ray of the Day-to be given on rare occasions for actions to substantially advance progress in global climate talks."12 This was done as part of the well-attended "Fossil of the Day" presentations inside the COP, which were covered by a range of media and had videos were posted online. This illustrates one of the many ways that civil society inside the COP linked with civil society outside both in Copenhagen and across the world via modern communications technology.

Restrictions on the number of NGO delegates allowed in started during the second week and became more severe towards the end of that week. I was one of only 300 NGO delegates that received a pass for the final Thursday and Friday due to a fire restriction limit of 15,000 people. A large contingent of government delegates and staff accompanied the 120 heads of state attending the final stages. ${ }^{13}$

There were, however, many more than 300 NGO delegates with access for the final two days, because when the restrictions were announced, many governments added key NGO delegates to their official delegations. At a UNFCCC meeting with the NGO constituency focal points, the UNFCCC noted that on that second Wednesday, 3,000 additional delegates were registered to take part in the meeting,${ }^{14}$ mostly NGO delegates who were to have been excluded. NGO delegates were added to the US and Australian official national delegations. ${ }^{15}$ I have been told but have been unable to confirm that China added all the Chinese NGO delegates to its official delegation. I can, however, find among the final list of official Chinese delegates, two representatives from Greenpeace and one from WWF. ${ }^{16}$ As a result of NGO exclusion, many NGO representatives had more privileged access as they were members of government delegations. The final number of delegates registered under official government delegations rose from the 8,041 initially reported by the UNFCCC ${ }^{16}$ to $10,591,{ }^{17}$ indicating that over 2,500 NGO delegates may have become government delegates.

Fisher said the call to storm the Bella Center posted on the internet "con-

11. See, for example "COP15 Tuvalu Rally," at http://www.youtube.com/watch?v=Sshga4vXrEE, accessed 21 May 2010.

12. CAN International and Avaaz.org 2009.

13. UNFCCC 2010.

14. Email sent by RINGOs to members: Preliminary report on UNFCCC Constituencies Focal Points meeting of 4 March 2010.

15. UNFCCCC 2010.

16. Fisher $2010,13$.

17. UNFCCC 2010. 
tributed to the decision to limit access to NGO delegations." 18 The issues leading to the restrictions had more to do with the fire restriction capacity limit and security concerns, with 120 world leaders attending. The Danish security forces were well set up to prevent any efforts to storm the venue.

\section{Disenfranchisement and the Copenhagen Accord}

As Dimitrov documents, COP-15 "was a failure whose magnitude exceeded our worst fears, and the resulting Copenhagen Accord was a desperate attempt to mask that failure." ${ }^{19}$ Disenfranchisement of much of global society, both countries and civil society was manifest in the process that resulted in the Copenhagen Accord.

A recent report, based on unauthorized audio recordings, of the negotiations on the final day of the COP between the leaders of 25 countries convened by the Danish Prime Minister documents the deadlock on a draft agreement. ${ }^{20}$ Not only was civil society disenfranchised by these negotiations, so were many of the 100 national leaders and the lead negotiators of other countries not represented in this select group. The drafts of the final declaration under discussion by the select group included provisions not only for limiting the rise of global temperatures to $2^{\circ} \mathrm{C}$ above pre-industrial levels by 2050, but, unlike the final Copenhagen Accord, they also indicated how this might be achieved. There was mention of reducing greenhouse gas emissions by 80 percent by 2050 and even the possibility of a mid-term goal by $2020 .{ }^{21}$

When the group of 25 failed to reach agreement, President Obama agreed with the leaders of China, India, Brazil and South Africa a minimalist agreement with no reference to specific emission reduction targets, which became the Copenhagen Accord. In this final stage, even the EU was excluded from the process. $^{22}$

This final act of disenfranchisement enabled President Obama to try to claim progress by announcing the Copenhagen Accord at 10.30pm on 18 December, the final scheduled day of the meeting. He asserted that we have "made a meaningful and unprecedented breakthrough here in Copenhagen. For the first time in history all major economies have come together to accept their responsibility to take action to confront the threat of climate change." ${ }^{23}$ At $11 \mathrm{pm}$, although civil society representation in the COP was diminished, CAN International held a press conference, webcast both in the COP and outside, declaring the Copenhagen Accord a "non-deal." 24

18. Fisher 2010, 15.

19. Dimitrov 2010, 18.

20. Rapp, Schwägerl, and Traufetter 2010.

21. Becker 2009.

22. Rapp, Schwägerl, and Traufetter 2010.

23. Office of the Press Secretary 2009.

24. UNFCCC 2009a. 
Mexico $^{25}$ and Australia ${ }^{26}$ (both members of the group of 25) held press conferences that were supportive of the Accord. The EU's press conference reflected its concerns about the weakness of the Copenhagen Accord and was less positive, noting "this was not a perfect agreement" and "it will not solve the climate threat." 27

The Danish Prime Minister presented the Copenhagen Accord, "developed by a representative group of leaders from all groups around the world" to the final plenary of the COP at 3 am on 19 December. ${ }^{28}$ Disenfranchisement was one of two major concerns then expressed by some countries. Seven countries openly opposed the Accord in the plenary as "undemocratically created, and too weak to save the world." ${ }^{29}$ Tuvalu was the first country to object, indicating that announcing a deal by press conference "is disrespectful of the UN processes" and that we were "being offered money to betray our people and our future, however, our future is not for sale." The latter statement generated applause in the plenary, even at 3.15am..$^{30}$ Venezuela, Cuba, Sudan and Bolivia supported Tuvalu. Bolivia commented that it was "most surprised and offended by the methodology that has been used," that millions of people are threatened by climate change and "we are being told that we have one hour to decide on the rights of those millions of people, we do not believe that this is respectful." 31

Nicaragua then proposed an alternative set of decisions for adoption that included a requirement that the developed country parties to the Kyoto Protocol negotiate the details of second commitment period by June 2010. Following this proposal, the meeting was suspended. ${ }^{32}$ The eventual outcome was that the Copenhagen Accord was not adopted but only noted. This occurred after over five hours of further discussion and following the replacement of the Danish Prime Minister as Chair of the COP. ${ }^{32}$ The phrase used- "take note" -merely acknowledges the existence of the Copenhagen Accord. Without strong support from environmental and climate justice groups for a fair, ambitious and binding outcome from COP-15, the seven countries may not have been willing to challenge the US, EU, China, India and Brazil, which had all endorsed the Copenhagen Accord.

At COP-15, there was the full emergence of a new and powerful alliance of environmental and climate justice groups with the vulnerable countries most at risk from climate change. This alliance had begun at the Bali COP in 2007 and played a major role at COP-15. ${ }^{33}$ Disenfranchisement was indeed widespread at

25. UNFCCC $2009 f$.

26. UNFCCC 2009 e.

27. UNFCCC $2009 \mathrm{~d}$.

28. UNFCCC 2009b.

29. Dimitrov 2010, 20.

30. UNFCCC 2009d.

31. UNFCCC 2009d.

32. UNFCCC 2009c.

33. Presentation by Cam Walker, Friends of the Earth International, From Global Crisis To Green Future conference, Sydney, 29 May 2010. 
COP-15, but it was not confined to civil society that had many actors working cooperatively with state actors and in the latter stages, some who became official government delegates. Many were pushing for a fair, ambitious and binding outcome from the COP. Regrettably, this outcome was not achieved.

\section{References}

350.org. 2009a. The 350 Movement: A Video Retrospective. Available at http:// action.350.org/p/salsa/web/common/public/content?content_item_KEY $=6821$, accessed 25 May 2010.

350.org. 2009b. Countries for 350 ppm/1.5 C. Available at http://www.350.org/media/ 350countries, accessed 10 September 2010.

Athanasiou, Tom. 2010. After Copenhagen: On being sadder but wiser, China, and justice as the way forward, Available at http://www.ecoequity.org/2010/01/aftercopenhagen/, accessed 24 May 2010.

Becker, Markus. 2009. Failure in Copenhagen Gunning Full Throttle into the Greenhouse. SpiegelOnline. Available at http://www.spiegel.de/international/world/ 0,1518,668111,00.html, accessed 23 May 2010.

CAN. 2009. Fair, Ambitious \& Binding: Essentials for a Successful Climate Deal, Climate Action Network, Available at http://www.climatenetwork.org/publication/ cans-fair-ambitious-binding-essentials-successful-climate-deal, accessed 30 October 2010.

CAN International and Avaaz.org. 2009. Ray of the Day. Available at http://www .fossiloftheday.com/?page_id=12, accessed 30 April 2010.

della Porta, Donatella, and Sidney Tarrow, eds. 2005. Transnational Protest and Global Activism. Lanham, MD: Rowman \& Littlefield.

Dimitrov, Radoslav S. 2010. Inside Copenhagen: The State of Climate Governance. Global Environmental Politics 10 (2): 18-24.

Fisher, Dana R. 2010. COP-15 in Copenhagen: How the Merging of Movements Left Civil Society Out in the Cold. Global Environmental Politics 10 (2): 11-17.

Fisher, Dana R., and Jessica Green. 2004. Understanding Disenfranchisement: Civil Society and Developing Countries' Influence and Participation in Global Governance for Sustainable Development. Global Environmental Politics 4 (3): 65-84.

Office of the Press Secretary, The White House. 2009. Remarks by the President during press availability in Copenhagen. Available at http://www.whitehouse.gov/thepress-office/remarks-president-during-press-availability-copenhagen, accessed 25 May 2010.

Rapp, Tobias, Christian Schwägerl, and Gerald Traufetter. 2010. How China and India Sabotaged the UN Climate Summit. SpiegelOnline. Available at http://www.spiegel .de/international/world/0,1518,692861,00.html, accessed 23 May 2010.

Sikkink, Kathryn. 2005. Patterns of Dynamic Multilevel Governance and the InsiderOutsider Coalition. In Transnational Protest and Global Activism, edited by Donatella della Porta and Sidney G. Tarrow, 151-174. Lanham, MD: Rowman \& Littlefield.

Tarrow, Sidney. 2005. The Dualities of Transnational Contention: "Two Activist Solitudes" or A New World Altogether? Mobilization: An International Quarterly 10 (1): $53-72$.

UNFCCC. 2009a. CAN International Press Conference, December 18. Available at http:// 
cop15.meta-fusion.com/kongresse/cop15/templ/play.php?id_ kongresssession $=2750 \&$ theme $=$ unfccc, accessed 28 May 2010 . . 2009b. Conference of the Parties (COP) resumed 9th Meeting at its 5th session. Copenhagen, Denmark, 19 December 2009, 3am. Available at http://cop15.metafusion.com/kongresse/cop15/templ/play.php?id_kongresssession=2753\&theme $=$ unfccc, accessed 28 May 2010.

2009c. Conference of the Parties serving as the meeting of the Parties to the Kyoto Protocol (CMP), resumed 12th Meeting, 5am, 19th December. Available at http:// cop15.meta-fusion.com/kongresse/cop15/templ/play.php?id_kongresssession $=2761$ \& theme $=$ unfccc, accessed 28 May 2010 .

. 2009d. Conference of the Parties to the UNFCCC serving as the meeting of the Parties to the Kyoto Protocol (CMP), resumed 12th meeting, 3.10am. Available at http://cop15.meta-fusion.com/kongresse/cop15/templ/play.php?id_ kongresssession $=2755 \&$ theme $=$ unfccc, accessed 28 May 2010.

. 2009e. Delegation of Australia Press Conference, December 19. Available at http://cop15.meta-fusion.com/kongresse/cop15/templ/play.php?id_ kongresssession $=2751$ \&theme $=$ unfccc, accessed 28 May 2010.

2009f. Delegation of Mexico Press Conference, December 19. Available at http:// cop 15.meta-fusion.com/kongresse/cop 15/templ/play.php?id_ kongresssession $=2743 \&$ theme $=$ unfccc, accessed 28 May 2010.

. 2010. List of participants Part One Parties (A-O), Available at http://unfccc.int/ resource/docs/2009/cop15/eng/inf01p01.pdf, accessed 31 October 2010. 